\title{
FOREIGN DIRECT INVESTMENT IN ASEAN COUNTRIES, 1990-2012
}

BHATT, P.R.*

\begin{abstract}
The objectives of the paper are to study foreign trade and investment dimensions of ASEAN and to study the role of FDI to the growth of exports. Vector autoregression model (VAR) is adopted to estimate the long run causal relationship between exports, foreign direct investment and GDP. The cointegration test result shows that there exists a long run equilibrium relationship between exports, FDI and GDP. It is found from the estimated Error Correction Model that FDI is a significant variable and the result indicates that 1 unit increase in FDI in ASEAN will lead to 1.1 units increase in exports. Wald Test indicates that there is a bilateral relationship between Exports and FDI but unilateral relationship between FDI and GDP and the direction is from FDI to GDP which means that FDI causes GDP. JEL classifications: F14, F21, F23
\end{abstract}

Key words: FDI, Exports, ASEAN, Error Correction Model, Cointegration, Causality

\section{Introduction}

The Association of South East Asian Nations (ASEAN) was created in 1967 through Bangkok Declaration by a group of five nations, viz., Indonesia, Malaysia, Philippines, Singapore and Thailand. Later Brunei Darussalam joined the group in 1984, Vietnam in June 1995, Myanmar and Laos in July 1997 and Cambodia in 1998. The ASEAN countries share a common economic philosophy of increasingly allowing market forces to drive their economies, which brought efficiency and prosperity to the region. The main objectives ASEAN are inter alia to accelerate economic growth, social progress and cultural development in the region and to promote trade and investment.

The gross domestic product (GDP) of ASEAN was US $\$ 2.3$ trillion (at current price) with per capita GDP of US \$ 3748 in 2013. In ASEAN region, Thailand has the highest GDP of US \$ 366 billion followed by Malaysia (US $\$ 303$ billion), Singapore (US $\$ 276$ billion), Philippines (US\$ 251 ) and Vietnam (US\$ 138 billion) in 2013ii. ASEAN GDP has grown at the rate of 5.7\% per annum and Phillipines has shown the highest growth rate of $6.8 \%$ among ASEAN countries in 2012 iii. The ASEAN countries have enjoyed a robust economic growth since 1975. High Foreign Direct Investment (FDI) had contributed to high levels of investment and employment generation, rising productivity and skill development and sharply improved export performance. The ASEAN economies had acted as a magnet to attract inward investment flows. FDI acted as both cause and effect in economic growth and facilitated economic upgrading. ASEAN region has become one of the most attractive investment regions in the developing world which attracted FDI stock to the tune of US\$ 1.3 trillion in $2012^{\text {iv }}$. ASEAN was highly exports-dependent region with exports-GDP ratio of $54.3 \%$ and its member countries export-GDP ratio varied between $21 \%$ to $148 \%$ in $2012^{v}$. The ratio of total trade to GDP for ASEAN was 107\% in 2012vi.

The objectives of the paper are (i) to study foreign trade and investment dimensions of ASEAN (ii) to study the role of FDI to the growth of exports in ASEAN.

The paper is organized as follows. Section 2 is devoted to survey of literature. Section 3 compares fundamentals of ASEAN countries and section 4 analyses foreign direct investment. Section 5 discusses ASEAN model, its estimates and analysis and section 6 concludes the discussions.

\footnotetext{
* Prof. Dr. P R Bhatt, Professor, Othman Yeop Abdullah Graduate School of Business, Universiti Utara Malaysia, 06010 Sintok, Malaysia
} 


\section{A Survey of Literature}

There is an emerging consensus that FDI inflows depend on the motives of foreign investors. Motives of foreign investors can be broadly classified as (i) market seeking (ii) resource or asset seeking and (iii) efficiency seeking. Market seeking FDI is to serve local and regional markets. Tariff-jumping or export-substituting FDI is a variant type of this FDI. Market size and market growth of the host country are the main drivers. In the case of resources or asset seeking FDI, investors are looking for resources such as natural resources, raw materials or low-cost labour. This vertical-export oriented FDI involves relocating parts of the production chain to the host country. Resources like oil and natural gas, iron ore, cheap labour attracted FDI in these sector. Efficiency seeking FDI occurs when the firm can gain from the common governance of geographically dispersed activities in the presence of scale and scope. One important variable explaining the geographical distribution of FDI is agglomeration economics. Investors simply copy investment decision taken by others. The common sources of these positive externalities are knowledge spillovers, specialized labour and intermediate inputs. A seminal work by Wheeler and Mody (1992) makes a strong case for agglomeration (and market size) in US investors' location decisions. The theory of agglomeration economics argue that once countries attract the first mass of investors, the process will be self-reinforcing without needing a change in policies (Wheeler and Mody 1992) whereas factor endowments theory argues that FDI is drawn to those countries where lower wages and more abundant natural resources prevail. Dunning's eclectic paradigm developed a comprehensive and holistic approach to explain the level and the pattern of international production (Dunning 1988, 1993). Dunnings analyzed FDI inflows based on three sets of factors viz., ownership specific advantage (O), locational advantage (L) and presence of superior commercial benefits in exploiting both O-type and L-type advantage internally (I) and directly rather than in exchanging them on market through licensing or cooperation agreements with an independent foreign firm. Ownership advantages are those that are specific to a particular firm and that enable it to take advantage of investment opportunities abroad. Locational advantages are those advantages specific to a country which dictate the choice of production site. Internalization advantages determine whether foreign production will be organized through markets (licensing) or hierarchies (FDI). The location of FDI has been traditionally been explained through the classical sources of comparative advantage (Ricardo, 1817). Firms locate production operation abroad to generate locational advantages that arise from direct access to growing markets, lower labour costs, reduced transportation and communication costs, avoidance of tariffs and nontariffs barriers and direct access to raw materials and intermediate products that are indispensible for the production of certain goods. Locational factors that ensure cost minimization are determined by relative factor prices, market size and growth (Kravis and Lipsey 1982, Veugelers 1991) as well as transportation cost (Aliber 1970). The ownership advantage of firms is ownership rights over patents, trademarks, commercial secrets and production process there by effectively denying access to both foreign and domestic competitors. FDI is often used to overcome barriers to entry into a foreign market, including tariff and non-tariff barriers (Motta 1992). Markuseu and Venables (1995) argued that multinational enterprises (MNEs) reduced the agglomeration forces that arise when international factor mobility is allowed. Wheeler and Mody (1992) had identified three sources of agglomeration economics viz., infrastructural quality, the degree of industrialization and the existing level of FDI. The location preference of foreign investors attempts to link the host country choice with basic motivation for undertaking the investment (Dunning 1998). Resource seeking investors locate production plants where necessary resources are available while efficiency seeking foreign investors is attracted to those countries well endowed with factors of production such as low-cost labour. Market 
seeking firms choose countries that offer the best opportunities for entering and expanding within the domestic or regional market while strategically motivated FDI may link one of the above motivations with strategic consideration. Strategic FDI is quite similar to resource seeking FDI (Dunning 1998). According to Mundell (1957) FDI flows into those countries that are importing goods from abroad. Vernon (1966) argues that adequate infrastructure is required to migrate production abroad. Within the basic framework of OLI, Dunnings (1981) had developed a theory of Investment Development Path (IDP) which evolved five stages of development viz. pre-industrialization with no FDI, inflow of FDI, outflow of FDI, but net inward FDI stock, net outward FDI and finally high stocks of both inward and outward FDI. The final stage represented international integration of industrialization. There would be variation of IDP theory across the countries based on their economic structure (Dunning and Narula, 1996).

Oscar Bajo-Rubio and Simon Sosvilla-Rivero (2001) in their empirical analysis of FDI inflows in Spain during the period 1964-84, found that FDI was explained by GDP (proxy for the size of Spanish market), inflation rate (proxy for macroeconomic instability), unit labour cost, unit capital cost, a measure of trade barriers, real effective exchange rate of the Peseta against the industrialized countries, a dummy variable for the year after the Spanish integration into EC and the lagged value of the foreign capital stock. Bhatt (2000) in his study of Foreign Direct Investment in ASEAN Economies found that there was a positive influence of the size of the economy (GNP) on FDI inflows in Indonesia and Singapore. The investment-GNP ratio was a significant factor for FDI inflows in Malaysia. The openness of the economy was significant factor in attracting FDI for Malaysia, the Philippines and Thailand. Ferris et al (1994) found that variables such as imports, exports, GDP, number of commercial vehicles used (proxy for a measure of infrastructure development) and political risks explained FDI inflows in Latin American countries. Yang et al (2000) addressed the issue of determinants of FDI inflow into Australia and found that FDI inflow was explained by short-term interest rate, real GDP, the trade-weighted index of the exchange rate, international trade as a fraction of GDP, a measure of labour disputes, wage costs and inflation rate. Erdal and Tatoglu (2002) found the existence of a linear relationship between FDI and the size of domestic market, openness of the economy to foreign trade, infrastructure of the host country, attractiveness of the domestic market, external and internal economic stability. Janicki and Wunnava (2004) estimated the determinants of FDI inflows in nine central and east European countries (CEEC) from 14 European Union countries for the year 1997. They found that international trade, GDP, difference in labour cost explained FDI inflows in European Union countries. Nicholas Billington (1999) analyzed the factors that determined the choice of location for FDI. He estimated a multi-country model with seven industrialized countries and eleven regions of UK. At country level, he found that market size (income and growth), unemployment, level of host country imports and policy such as corporate tax and interest rates were significant determinants of location for FDI inflows. Campos and Kinoshita (2003) studied the determinants of FDI inflows in 25 transition countries of Central Europe and in the former Soviet Union for the period 19901998 and found that the main determinants of FDI inflows to those countries were agglomeration which were proxied by lagged FDI, labour cost, abundance of natural resources, economic reforms, good institutions and quality of bureaucracy. Nonnemberg and Cardoso de Mendonca (2002) have studied the determinants of FDI inflows for 38 developing countries including transition economies for the period 1975-2000 and found that both the size of the economy as measured by GDP and average rate of growth, degree of openness, inflation and capital market growth proxied by Dow Jones positively affected the inflows of FDI. Laura Resmini (2000) investigated the determinants of European Union FDI in the Central and East European Countries (CEECs) at sectoral level during the period 1991- 
95. GDP per capita, population, the Operation Risk Index and wage differentials were significant factors of FDI inflows. Erdal and Tatoglu (2002) provided an empirical analysis of location-related determinants of FDI inflows in Turkey for the period 1980-1998 and their empirical results showed that the size of the domestic market, physical infrastructure, openness of the economy and market attractiveness proxied by growth rate of real GDP were significant factors responsible for FDI inflows. A causal relationship among macroeconomic variables such as exports, FDI and income are intrinsically related to a country's economic structure. There exists extensive surveys of literature on the relationship between exports, FDI and income such as Harrison (1996), Dollar (1992), Krueger ( 1985) and Thornton (1996). Exports and FDI are fundamentally substitutes to each other (Dunning, 1977). Bhagavati (1978) points out that volume and efficiency of FDI are more pronounced in export oriented host countries. Helleiner (1973) explained the role of MNCs in manufacturing exports of LDCs. FDI is essentially a driving force behind China's rapid expansion (Xing, 2006). FDI in China facilitated it's exports to the FDI source countries (Liu, Wang and Wei,2001). FDI has substantially enhanced Vietnam's exports to its source countries (Xuan and Xing, 2008). Sun (2001) found that FDI has positive and strongest impact on in the coastal region of China. Zhang and Song (2000) found that higher level of FDI led to higher level of provincial exports in China. Barry and Bradley (1997) concluded that there has been a significant direct contribution of foreign producers to increasing Irish exports. Girma et al (2007) found that FDI affects productivity of the acquired firms by the foreign country. Other studies which have shown a significant positive econometric relationship between inward FDI and the host country's exports are Lin (1995), Leichenko and Erickson (1997), Pain and Wakelin (1998), Hejazi and Zafarian (2001), Liu and Shu (2003), Metwally (2004), Zhang (2005). On the other hand Zhang and Felmingham (2001), and Ekanayake, Vogel and Veeramacheneni (2003) found a one-way causality from exports to inward FDI ("exports causes FDI").

\section{Fundamentals of ASEAN countries.}

Average annual GDP growth rate of ASEAN was $5.4 \%$ and the growth rates varied among its member countries from Phillppine's $6.6 \%$ to Singapore's $1.2 \%$ in 2012 vii. The growth rate achieved by ASEAN members was because of their policy towards private enterprises and foreign direct investment. They have adopted entrepreneur friendly policies which helped private entrepreneurs to invest heavily to take advantage of the opportunity available in the region. The per capita growth of ASEAN was $4.2 \%$ in 2012 viii. The average annual per capita GDP growth was highest for Thailand (5.8\%) and lowest for Singapore (0\%) in 2013 $3^{\text {ix. The }}$ per capita income varied from the highest of US \$ 52069 for Singapore and lowest of US\$ 1596 for Vietnam in 2012x. ASEAN considered trade as engine of growth for the region. Share of exports in world's exports in ASEAN countries varies from $1.4 \%$ in Indonesia to $0.29 \%$ in Vietnam in 2012xi. The share of exports of Singapore in its GDP was 147\% and imports 137 $\%$ in 2012xii. In the case of Malaysia the share of exports in its GDP was 75\% and imports $64 \%$ in 2012 xiii.

The structure of ASEAN economy indicated that service sector was dominated with $46.9 \%$ of GDP and industry sector with $40 \%$ and Agriculture sector $13.1 \%$ in 2012xiv. Manufacturing sector constituted $23.9 \%$ of its GDP in $2012^{\mathrm{xv}}$. Industry sector is dominated in Malaysia, Indonesia and Vietnam whereas services sector dominated in Singapore, Philippines and Thailand in their GDPxvi. Malaysia, Thailand and Vietnam have shown high growth rate in industry sector whereas Indonesia, Philippines and Vietnam have shown moderate growth in service sector in $2012^{x v i i}$. The high industry sector growth has resulted high over all growth of the economy. The high industry growth also has resulted high FDI inflow as FDI is normally attracted to the industry sector (Bhatt 2008a). Manufacturing is the engine of 
growth as industrial goods have a higher-income elasticity of demand (Kaldor, 1967). The growth of manufacturing sector resulted faster growth of GDP of Malaysia, Indonesia and Vietnam. It pursued a dynamic industrial policy to encourage industries through trade and investment. It is important to see that service sector also grew in tandem with industry sector because any significant imbalances between the two affect consumption and investment efficiency.

\section{Foreign Direct Investment (FDI) inflows ASEAN Countries}

High FDI inflows in the region contributed high level of investment and employment generation, raising productivity and skill development and sharply improved competitiveness (Bhatt 2008b). ASEAN is an open economy region with low barriers for trade and foreign direct investment. FDI in ASEAN was both efficiency-seeking and marketseeking which helped the expansion of manufacturing and trade in the region. FDI inflows in ASEAN have increased from US\$ 12.8 billion in 1990 to US \$ 111.3 billion in 2012 (Table 1).

Singapore has attracted the highest FDI inflows to the tune of US\$ 56.7 billion followed by Indonesia (US \$ 19.8 billion), Malaysia(US \$10.1 billion) Thailand (US\$ 8.6 billion), Vietnam (US\$ 8.4 billion) and Philippines (US \$2.8) in 2012 (Table 1). FDI inward stock of the region was US\$ 1320 billion in 2012 which has increased from US \$ 64.3 billion in 1990 (Table 2). The FDI stock was highest of US\$ 682 billion for Singapore followed by Indonesia (US \$ 205.7 billion), Thailand (US\$ 159.1 billion) and Malaysia (US \$ 132.4 billion) in 2012 (Table 2). FDI inflows have contributed immensely to its industrial structure. The region has adopted an investment-led industrial policy which helped foreign investors to invest in the region in a big way. Even though ASEAN has encouraged FDI inflows, it made sufficient surplus internally to finance its manufacturing sector. Many multinational companies entered the region through mergers and acquisition (M\&As) to take advantage of opportunities.

Table 1: FDI inflows (millions of \$)

\begin{tabular}{|c|c|c|c|c|c|c|c|}
\hline Year & Indonesia & Malaysia & Philippines & Singapore & Thailand & Vietnam & ASEAN \\
\hline 1990 & 1092 & 2611 & 550 & 5575 & 2575 & 180 & 12821 \\
\hline 1995 & 4419 & 5815 & 1459 & 11535 & 2070 & 1780 & 28227 \\
\hline 2000 & -4495 & 3788 & 2240 & 16484 & 3410 & 1289 & 23656 \\
\hline 2005 & 8337 & 4064 & 1854 & 15460 & 8967 & 2021 & 40734 \\
\hline 2009 & 4877 & 1381 & 1948 & 16809 & 5949 & 4500 & 36806 \\
\hline 2010 & 13771 & 9060 & 1298 & 53623 & 9147 & 8000 & 97898 \\
\hline 2012 & 19853 & 10074 & 2797 & 56651 & 8607 & 8368 & 111336 \\
\hline
\end{tabular}

Source: UNCTAD: World Investment Report, 2013

Table 2: Stock of FDI inflows (billions of \$)

\begin{tabular}{|c|c|c|c|c|c|c|c|}
\hline Year & Indonesia & Malaysia & Philippines & Singapore & Thailand & Vietnam & ASEAN \\
\hline 1990 & 8.7 & 10.3 & 4.5 & 30.5 & 8.2 & 1.7 & 64.3 \\
\hline 1995 & 20.6 & 28.7 & 10.1 & 65.6 & 17.7 & 7.2 & 152.5 \\
\hline 2000 & 25.1 & 52.7 & 18.2 & 110.6 & 29.9 & 20.6 & 267.0 \\
\hline 2005 & 41.2 & 44.5 & 15.0 & 194.6 & 60.4 & 31.1 & 404.3 \\
\hline 2009 & 72.8 & 74.6 & 23.6 & 343.6 & 99.0 & 52.8 & 690.0 \\
\hline 2012 & 205.7 & 132.4 & 31.0 & 682.4 & 159.1 & 72.5 & 1319.5 \\
\hline
\end{tabular}

Source: UNCTAD: World Investment Report, 2013 


\section{ASEANModel}

Following the model which has been used in empirical literature (Baltagi, 1995), the general model that we have adopted in our study can be written as

$y_{i t}=\alpha+\beta X_{i t}+v_{i}+\xi_{i}+\epsilon_{i t}$

$y_{i t}$ denotes dependent variable for country i at period $t, \alpha$ is constant, $\beta$ is $\mathrm{px} 1$ vector and the independent variables is the it-th observation on the $\mathrm{p}$ number of determinant variables. The term $v_{i}$ is the unobservable cross-sectional unit specific residual that accounts for individual effects, the term $\xi_{t}$ is the unobservable time specific residual that accounts for period effects and the term $\epsilon_{i \varepsilon}$ is the usual error term after taking out the individual and period effects. The fixed effect specification assumes that country-specific effects are fixed parameters to be estimated, whereas the random effect model assumes that countries constitute a random sample. The fixed effects model allows the unobserved country effects to be correlated with the explanatory variables. The random effect model is more appropriate if there is correlation between the fixed effects and the determinants. The random effects model assume that the country effects, either cross-section or period, are randomly distributed across the individual country and time, respectively. This assumption is valid if the sample is assumed to be drawn randomly from a large population. In the random effects model, both the cross section and the period specific effects, $v_{i}$ and $\xi_{z}$, are no longer a constant or a set of fixed parameters to be estimated. Instead, both $v_{i}$ and $\xi_{t}$ are now a random error term with a mean value of zero and variance of $\sigma v_{\bar{i}}^{2}$ and $\sigma \xi_{\bar{t}}^{2}$ respectively.

We have employed panel data estimation techniques to estimate the model. Panel regression offer great flexibility in modeling heterogeneity bounded in firm-specific performance, as well as for temporal changes in the firms' operating environment.

In the general model mentioned above our dependent variable is exports (EXP) and independent variables are

foreign direct investment (FDI),

gross domestic product(GDP),

capital stock $(\mathrm{K})$ and

exchange rates(XR).

However variables capital stock and exchange rates have been dropped from the model as they are not significant in the estimated model. Moreover these two variables are correlated with FDI and GDP creating multicollinearity problem. The data that are used in this analysis are annual covering the period 1990-2012 and are obtained from International Monetary Fund: International Financial Statistics and UNCTAD: Handbook of Statistics.

As is customary in panel data analysis, we estimate both a fixed effect and a random effect model. 


\section{A Vector Autoregression Model (VAR) with an Error Correction Mechanism}

Vector Autoregression model (VAR) is adopted to estimate the long run causal relationship between exports, foreign direct investment and GDP.

\section{Unit Root Test}

Before testing the cointegration of two or more variables, it is essential to check whether the variables have unit root or not. The existence of unit root was tested by Levin, Lin and Chu test, Im, Pesaran and Shin W-stat, ADF test and PP test and the results were given in Table 3. It can be seen from the Table 3 that all variables viz. exports, GDP and FDI have unit root at level. Since all variables have unit root at level, then it is needed to see whether there exists at least one cointegration equation among the variables. The existence of cointegration is tested by several Pedroni panel cointegration test statistics. The cointegration test results are given in Table 4. It was found that three out of eleven test statistics have rejected the null hypothesis of no cointegration at a significant level of 5\%. Since there exists at least one cointegration relationship among the variables, a VAR model with an Error Correction can be estimated.

The Vector Error Correction Model takes the following form:

$\Delta$ exports $_{\mathrm{it}}=\operatorname{lagged}\left(\Delta\right.$ exports $\left._{\mathrm{it}}\right)+\Delta \mathrm{GDP}_{\mathrm{it}}+\Delta \mathrm{FDI} \mathrm{it}_{\mathrm{it}}+\beta \mathrm{e}_{\mathrm{it}-1}+v_{i}+\xi_{t}+\varepsilon_{i t}$

Where $\Delta$ is the first difference of the variables, $\mathrm{e}_{\mathrm{it}-1}$ is the estimated residuals from the cointegrated regression (long-run relationship) and represents the deviation from the equilibrium in time period t. $-1<\beta<0$, short-run parameter. The term $v_{i}$ is the unobservable cross-sectional unit specific residual that accounts for individual effects, the term $\xi_{z}$ is the unobservable time specific residual that accounts for period effects and the term $\epsilon_{i z}$ is the usual error term after taking out the individual and period effects.

Panel data estimation techniques are employed to run the regression. Panel regression offer great flexibility in modeling heterogeneity bounded in country-specific information. Hausman test was conducted to determine whether fixed effect and random effect estimators are consistent. The Hausman test will inform us regarding which model to stress; if the test is significant we focus on the fixed effect model, whereas we report the random effect model if the Hausman test is insignificant. It is found that Hausman test is significant and hence fixed effect model was used to estimate the error correction model.

The estimated Error Correction Model is given in Table 5. The model is highly significant with adjusted $\mathrm{R}^{2}=0.718227$. The error correction term has a negative sign and statistically significant. FDI is a significant variable in the short term in the model which indicates that one unit increase in FDI will lead to 1.1 units increase in exports with one year time gap. The result supported the earlier studies that FDI enhanced exports ( see for example Andraz and Rodridues, 2010, Xuan and Xing, 2008, Dritsaki et al ,2004, Leichenko and Erickson, 1997). As suggested by Dunnings (1981), ASEAN has reached stage 3 of Investment Path theory (IDP) by the stock of inward FDI. Wald Test indicates that there exist a bilateral relationship between exports and FDI; exports and GDP. However there is unilateral relationship between GDP and FDI and the causation is from FDI to GDP which means FDI causes GDP (Table 6). 
Table 3: Unit Root Test for Stationarity

\begin{tabular}{|c|c|c|c|c|c|c|c|c|c|c|c|c|}
\hline & \multicolumn{4}{|c|}{ Exports } & \multicolumn{4}{|c|}{ GDP } & \multicolumn{4}{|c|}{ FDI } \\
\hline & \multicolumn{2}{|c|}{ Level } & \multicolumn{2}{|c|}{$\begin{array}{c}\text { First } \\
\text { difference }\end{array}$} & \multicolumn{2}{|l|}{ Level } & \multicolumn{2}{|c|}{$\begin{array}{l}\text { First } \\
\text { difference }\end{array}$} & \multicolumn{2}{|c|}{ Level } & \multicolumn{2}{|c|}{$\begin{array}{c}\text { First } \\
\text { difference }\end{array}$} \\
\hline & Stat & Prob. & Stat & Prob. & Stat & Prob. & Stat & Prob. & Stat & Prob. & Stat & Prob. \\
\hline $\begin{array}{l}\text { Levin, Lin and } \\
\text { Chu t statistic } \\
\text { ( assume } \\
\text { common unit } \\
\text { root } \\
\text { process)** }\end{array}$ & 0.528 & 0.70 & 1.336 & 0.909 & 3.090 & 0.999 & -4.79 & 0.000 & -1.86 & 0.03 & -6.81 & 0.000 \\
\hline $\begin{array}{l}\text { Im, Pesaran } \\
\text { and Shin W- } \\
\text { statistic }\end{array}$ & 2.43 & 0.99 & -3.104 & 0.001 & 4.866 & 1.000 & -3.80 & 0.000 & -2.39 & 0.00 & -6.94 & 0.000 \\
\hline $\begin{array}{l}\text { ADF Test } \\
\text { Statistic }\end{array}$ & 2.00 & 0.99 & 26.143 & 0.004 & 1.360 & 1.000 & 31.82 & 0.000 & 21.53 & 0.02 & 57.96 & 0.000 \\
\hline $\begin{array}{l}\text { PP Test } \\
\text { Statistic }\end{array}$ & 2.00 & 0.99 & 26.054 & 0.004 & 0.409 & 1.000 & 30.85 & 0.000 & 17.01 & 0.07 & 84.30 & 0.000 \\
\hline
\end{tabular}

**Probabilities for Fisher tests are computed using an asymptotic Chi-square distribution. All other tests assume asymptotic normality

Table 4: Pedroni Residual Cointegration Test

\begin{tabular}{|c|c|c|c|c|}
\hline & Statistic & Prob. & $\begin{array}{c}\text { Weighted } \\
\text { statistic }\end{array}$ & Prob. \\
\hline Panel v-statistic & 2.423754 & 0.0077 & 0.318533 & 0.3750 \\
Panel rho-statistic & -2.172027 & 0.0149 & 0.130801 & 0.5520 \\
Panel PP-statistic & -3.666464 & 0.0001 & -0.063489 & 0.4747 \\
Panel ADF-statistic & -0.733100 & 0.2317 & 0.634236 & 0.7370 \\
Group rho-statistic & 0.529573 & 0.7018 & & \\
Group PP statistic & -0.315828 & 0.3761 & & \\
Group ADF & 0.781700 & 0.7828 & & \\
statistic & & & & \\
& & & & \\
\hline
\end{tabular}


Table 5: Vector Error Correction Model for Panel data for 1990-2012

\begin{tabular}{|c|}
\hline$\Delta$ Export $_{\mathrm{t}}=-0.211577 \mathrm{EC}_{\mathrm{t}-1}{ }^{* *}+0.019670 \Delta$ Export $_{\mathrm{t}-1}+1.095143 \Delta$ FDI $_{\mathrm{t}-1}{ }^{*}$ \\
\hline$(-2.473878) \quad(0.134912)$ \\
\hline$+0.101831 \Delta \mathrm{GDP}_{\mathrm{t}-1}{ }^{* *}+4365.784$ \\
\hline$(2.118009) \quad(2.605116)$ \\
\hline $\mathrm{R}^{2}=0.797377 \quad$ Adj $\mathrm{R}^{2}=0.718227 \quad \mathrm{DW}=1.838597$ \\
\hline$*$ indicate significant at $1 \%$ level, $\quad * *$ indicate significant at $5 \%$ level \\
\hline$\Delta$ indicates first difference \\
\hline
\end{tabular}

Table 6: Pair-wise Wald Tests for causality

\begin{tabular}{|l|c|c|c|c|c|c|}
\hline & F-Statistic & $\mathrm{df}$ & Prob & $\begin{array}{c}\text { Chi-Square } \\
\text { statistic }\end{array}$ & $\mathrm{df}$ & Prob \\
\cline { 2 - 7 } Exports do not cause FDI & 6.656930 & 2,97 & 0.0020 & 13.31386 & 2 & 0.0013 \\
\hline FDI do not cause Exports & 9.703080 & 2,97 & 0.0001 & 19.40616 & 2 & 0.0001 \\
\hline Exports do not cause GDP & 59.59443 & 2,97 & 0.0000 & 119.1889 & 2 & 0.0000 \\
\hline GDP do not cause Exports & 58.83575 & 2,97 & 0.0000 & 117.6715 & 2 & 0.0000 \\
\hline FDI do not cause GDP & 0.918218 & 2,97 & 0.4027 & 1.836437 & 2 & 0.3992 \\
\hline GDP do not cause FDI & 3.451905 & 2,97 & 0.0356 & 6.903811 & 2 & 0.0317 \\
\hline
\end{tabular}

\section{Summary and Conclusion}

Average annual GDP growth rate of ASEAN was $5.4 \%$ and the growth rates varied among ASEAN countries in 2012. The per capita growth of ASEAN was 4.2\% in 2012. ASEAN considered trade as engine of growth for the region. Industry sector dominated in Malaysia, Indonesia and Vietnam whereas services sector dominated in Singapore, Philippines and Thailand in their GDP. Malaysia, Thailand and Vietnam have shown high growth rate in industry sector whereas Indonesia, Philippines and Vietnam have shown moderate growth in service sector in 2012. The high industry sector growth has resulted high over all growth of the economy. FDI inflows in ASEAN have increased from US\$ 12.8 billion in 1990 to US \$ 111.3 billion in 2012. FDI inward stock of the region was US 1319 billion in 2012 which has increased from US \$ 64.3 billion in 1990. FDI inflows have contributed immensely in its industrial structure. A vector autoregression model (VAR) is adopted to estimate the long run causal relationship between exports, foreign direct investment and GDP. The cointegration test result shows that there exist a long run equilibrium relationship between FDI, GDP and Exports. It is found that FDI is a significant variable and the result indicates that 1 unit increase in FDI in ASEAN will lead to 1.1 units increase in exports with one year time gap. Wald Test of Causality indicates that there is a bilateral relationship between Exports and FDI in ASEAN but unilateral direction from FDI to GDP. 


\section{References}

Aliber, R Z.1970. A Theory of Foreign Direct Investment. In CP Kindleberger (Ed.)

The International Corporation: Cambridge, 17-34.

Andraz, Jorge Mand Paulo M Rodrigues. (2001). What causes economic growth in Protugal: exports or inwards FDI. Journal of Economic Studies. 37(3). 267,287.

Baja-Rubio Oscar; \& Sosvilla-Rivero, Simon. 2002. On the Determinants of Foreign Direct Investment to Developing countries: Is Africa Different. World Development, 30(1),107-119 Baltagi, Badi H.(1995). Econometric analysis of panel data. John Wiley \& sons, New York.

Barry, F and J Bradley (1997). FDI and trade: The Irish host country experience. Economic Journal. 107(445), 1798-1811.

Bhagawati, J N.(1973). The Theory of immiserizing growth: further application. In Michael B. Connolly and Alexander K.Swoboda (ed) International trade and money, Toronto, University of Toronto Press.

Bhatt, P.R .2000. Foreign Direct Investment in ASEAN Economies, Prajnan, 29(2) : 127-42

Bhatt P R .(2008a). Determinants of foreign direct investment in ASEAN. Foreign Trade Review, XLIII(3), October-December.

Bhatt P R . (2008b). Trade competitiveness and exchange rate policy in ASEAN. Anveshak_ 38(2), July-December.

Bhatt, P R. (2008c). India's trade competitiveness and exchange rate policy. Margin, 2(3), JulySeptember.

Billington, Nicholas .1999. The location of foreign direct investment: an empirical analysis Applied Economics, 31: 65-76.

Blomstrom, M and Persson, H. (1983). Foreign investment and spillover efficiency in an underdeveloped economy: Evidence from Mexican manufacturing industry. World development, 11(6), 493-501.

Campos, Nauro F; \& Kinoshita, Yuko .2003. Why does FDI go where it goes? New evidence from the Transition Economics Working Paper, IMF ,WP/ 83/ 228

Dritsaki, Melina, Chaido Dritsaki and Antonios Adamopoulos.(2004). American Journal of Applied Sciences.1(3), 230-235

Dollar,D. (1992). Outward-oriented developing economies really do grow more rapidly: evidence from 95 LDCs, 1976-1985. Economic Development and Cultural Change, 40, pp 523-544.

Dunning, J H. (1977). The determinant of international production. Oxford Economic Papers, 25(3), 289-330.

Dunning, J H. (1981). Explaining international direct investment position of countries: towards a dynamic and development approach. Weltwirtschaftliches Archiv.117, 30-64

Dunning , J.H. 1988. Explaining International production .London: Harper Collins.

Dunning , J.H.1988. The eclectic paradigm of international production: A restatement \& some possible extensions. Journal of International Business Studies, 30, 1-31.

Dunning , J.H. 1993. Multinational Enterprises \& Global Economy. New York: Addison Wesley.

Dunning , J.H. 2001. The Eclectic (OLI) paradigm of International Production: Past, present \& Future. International Journal of Economics \& Business, 8(2), 173-90.

Dunning , J.H. and Rajneesh Narula. (1996). The investment path revisited: some emerging Issues. In J H Dunnings and Rajneesh Narula. Eds. Foreign direct investment and governments. London: Routledge, 1-41 
Ekanayake, E.M., Vogel, R. and Veeramacheneni, B.(2003). Openness and Economic Growth: Empirical Evidence on the Relationship between Output, Inward FDI and Trade. Journal of Business Strategies, 20, 59-72.

Erdal, Fuat; \& Tatoglu, Ekrem. (2002). Locational Determinants of Foreign Direct Investment in and Emerging Market Economy: Evidence from Turkey. Multinational Business Review, spring.

Ferris, Stephen P G; Thompson Rodney; \& Valsan Calin. 1994. "Foreign Direct Investment in an Emerging Market Economy. Eastern European Economics, July-August.

Girma, S, R. Kneller and M. Pisu. (2007). Do exporters have anything to learn from foreign nationals. European Economic Review, 51 (4), pp.993-1010

Gujarati, D N. (2003). Basic Econometrics, $4^{\text {th }}$ edition, McGraw-Hill, Singapore

Hjalmarsson, Erik and Par Osterholm (2007). Testing for cointegration using the Johansen methodology when variables are near-integrated. IMF Working Paper.

Harrison, A.(1996). Openness and growth: a time series, cross-country analysis for developing countries. Journal of Development Economies, 48, pp419-47

Hejazi, W. and Safarian, A.E.(2001).The Complementarity between U.S. Foreign Direct Investment Stock and Trade. Atlantic Economic Journal, 29, 420-437.

Helleiner, G K (1973). Manufactured exports from less developed countries and multinational firms. Economic Journal, 83, 21-47.

IMF. International Financial Statistics, Annual. various issues.

Janicki, Hubert P; \& Wunnava Phanindra V. 2004. Determinants of Foreign Direct Investment :

Empirical Evidence from EU accession candidates Applied Economics 36: 505-509.

Kaldor, N (1967).Strategic Factors in Economic Development (Ithaca, NY: New York State School of Industrial and Labour Relations).

Kravis , I B; \& Lipsey, R. 1982 Locations of Overseas Production \& Production for Exports by US manufacturing firms. Journal of International Economics, 12, 201-23.

Krueger, A O. (1985). The experience and lessons of Asia super exporters. In Corbo, V, A O Krueger and F Ossa (eds). Export-oriented development strategies: The success of five newly industrialized countries, London: Westview Press, pp 197-201

Leichenko, Robin M and Rodney A Ecickson. (1997). Foreign Direct Investment ans state export performance. Journal of Regional Science.37(2), 307-329.

Lin, A.L.(1995). Trade Effects of Foreign Direct Investment: Evidence for Taiwan with Four ASEAN Countries. Weltwirtschafliches Archiv, 131, 737-747.

Liu, X.H. and Shu, C.(2003). Determinants of Export Performance: Evidence from Chinese Industries. Economics of Planning, 36, 45-67.

Liu, X., Wang, C.G. and Wei, Y.Q.(2001). Causal Links between Foreign Direct Investment and Trade in China. China Economic Review, 12, 190-202.

Markusen, J.R; \&Venables, A.J. Theory of endowment, intra-industry \& multinational trade. NBER Working paper 5529.

Motta, M. 1992. Multinational Firms \& the Tariff-jumping Argument. European Economic

Review 36, 1557-71

Mundell, Robert A. 1957. International Trade \& Factor Mobility. American Economic Review, 47 , 321-35.

Noorbakhsh, F; Paloni, A; \& Yousef, A. 2001. Human Capital \& FDI Inflows to Developing

Countries: New Empirical Evidence. World Development , 29 ( 9): 1593-610 
Resmini, Laura. 2000. The Determinants of Foreign Direct Investment in CEECS: New evidence from electoral patterns. Economics of Transition, 8( 3): 665-689.

Ricardo, David. ( 1971). The principles of political economy and taxation. J Murray, London. Originally published in 1817.

Sun, H.(2001). Foreign Direct Investment and Regional Export Performance in China. Journal of Regional Science, 41, pp.317-336.

Thornton, J. (1996). Cointegration, causality and export-led growth in Maxico, 1895-1992. Economic Letters. 50(3), 413-6

Vernon, R. (1966). International Investment and International Trade in the Product Cycle.

Quarterly Journal of Economics, 80: 190-207.

Veugelers, R. 1991. Locational Determinants and Ranking of Host Countries: An empirical assessment, Kyklos, 44, 363-82

Wheeler, David; \& Mody, Ashoka.1992. International Investment Location Decision: The

Case of US Firms. Journal of International Economics, 33, 57-56.

World Economic Forum. (2010). The Report of Global Competitiveness, 2010-11.

Xing, Y.(2006). Why is China so attractive to FDI? The role of exchange rates. China Economic Review, 17(2), pp.198-209

Xuan, Nguyen Thanh and Yuqing Xing. ( 2008). Foreign Direct Investment and Exports: The experience of Vietnam. Economics of Transition, 16(2), pp.183-197

Yang, Jeannie Yih Yun; Groenewold, Nicolaas; \& Tcha, Moonjoong. 2000. The Determinants of Foreign Direct Investment in Australia. The Economic Record, 76(232).

Zhang, Q. and Felmingham, B.(2001).The Relationship between Inward Foreign Direct Investment and China's Provincial Export Trade.

\footnotetext{
${ }^{\text {i }}$ ASEAN Secretariat, 2013

ii Global Competitive Index Report 2013

iii ASEAN Secretariat, 2013

${ }^{\text {iv }}$ UNCTAD. Global Investment Report 2013

${ }^{v}$ ASEAN Secretariat, 2013

${ }^{\text {vi }}$ ASEAN Secretariat , 2013

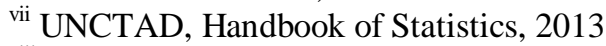

viii UNCTAD, Handbook of Statistics, 2013

${ }^{\text {ix }}$ UNCTAD, Handbook of Statistics, 2013

${ }^{x}$ ASEAN Secretariat, 2013

${ }^{x i}$ Global Competitive Index Report 2013

xii UNCTAD, Handbook of Statistics, 2013

xiii ibid

${ }^{\text {xiv }}$ UNCTAD, Handbook of Statistics, 2013

${ }^{\mathrm{xv}}$ ibid

${ }^{x v i}$ World Development Indicators

${ }^{\text {xvii }}$ UNCTAD, Handbook of Statistics, 2013
}

List of ASEAN countries: http://en.wikipedia.org/wiki/List_of_ASEAN_countries_by_GDP_(nominal)

Revista Galega de Economia/ Economic Review of Galicia: https:/ / ideas.repec.org/ s/ sdo/ regaec.html http:/ / www.usc.es/ econo/ RGE/ benvidag.htm 